Chin, Ayessa A et al / Int. J. Res. Ayurveda Pharm. 4(6), Nov-Dec 2013

Research Article

www.ijrap.net

\title{
ANTIMICROBIAL PERFORMANCE OF ETHANOLIC EXTRACT OF ARECA CATECHU L SEEDS AGAINST MIXED-ORAL FLORA FROM TOOTH SCUM AND GRAM NEGATIVE LABORATORY ISOLATES \\ Chin, Ayessa A. ${ }^{1}$, Fernandez Clariza D. ${ }^{1}$, Sanchez Renalyn B. ${ }^{1}$, Santos Beatriz Marie S. ${ }^{1}$, Tolentino Regine F. ${ }^{1}$, Masangkay Frederick R. ${ }^{2 *}$ \\ ${ }^{1}$ Bachelor of Science Student, Department of Medical Technology, Institute of Arts and Sciences, Far Eastern University-Manila, Nicanor Reyes Sr. St. Sampaloc Manila, Philippines \\ ${ }^{2}$ RMT, MSMT, Regular Full-Time Faculty, Associate Professor II, Department of Medical Technology, Institute of Arts and Sciences, Far Eastern University-Manila, Nicanor Reyes Sr. St. Sampaloc Manila, Philippines
}

Received on: 31/10/13 Revised on: 20/11/13 Accepted on: 09/12/13

\author{
*Corresponding author \\ E-mail: frederick masangkay2002@yahoo.com \\ DOI: $10.7897 / 2277-4343.04620$ \\ Published by Moksha Publishing House. Website www.mokshaph.com \\ All rights reserved.
}

\begin{abstract}
Areca catechu L. nut is a component of betel quid, the chewing of which is a popular or a cultural tradition in some countries in South East Asia. Areca nut contains bioactive components like alkaloids and tannins which have been demonstrated to elicit inhibitory effects in selected microorganisms. Varying concentrations of Areca catechu L. nut ethanol extract were tested for antimicrobial activity against 0.5 McFarland of mixed-oral flora and eight gram-negative clinical isolates (E. coli, K. pneumonia, P. vulgaris, P. aeruginosa, S. non-typhi, S. typhi, S. flexneri and V. cholera) by agar well diffusion method. All concentrations were shown to inhibit growth in all mixed-oral flora models with zones of inhibition ranging from $7 \mathrm{~mm}$ to $18 \mathrm{~mm}$. Susceptible patterns were also seen in all gram-negative clinical isolates with the smallest mean of zones of inhibition seen in Escherichia coli which is $8 \mathrm{~mm}$ at $30 \%$ concentration and Klebsiella pneumoniae with no zone of inhibition in both $30 \%$ and $50 \%$ concentration. Highest antimicrobial activities were seen against Proteus vulgaris and Vibrio cholerae with a mean zone of inhibition of 18 mm at 70 $\%$ concentration and a mean zone of inhibition of $16 \mathrm{~mm}$ at $50 \%$ concentration respectively. These results were comparable to intermediate susceptible pattern in Ciprofloxacin which is $16 \mathrm{~mm}$ to $20 \mathrm{~mm}$ and indicates that there are bioactive components present in areca nut that are worthy enough of further study and exploitation for its inherent antimicrobial activity.
\end{abstract}

Keywords: Areca catechu L., Agar-well diffusion, Betel nut, ethanol extract, Gram-negative bacteria, oral flora

\section{INTRODUCTION}

A common practice among Asians, most especially the elders is the chewing of betel quid commonly known as "nganga", a combination of betel nut, betel leaves with lime or tobacco. Chewing betel quid is considered a past time and is a cultural tradition in different countries like India, Indonesia, Arabian Peninsula, some of the Pacific islands such as Micronesia, Fiji, Solomon Islands and the Philippines ${ }^{1}$. Areca catechu L. is a straight solitary tree that has annular leaf scars. The leaves have leaflets that measure up to $4 \mathrm{~cm}$ long. The ovoid fruit turns red or orange when ripe and has a fleshy pericarp and a fibrous mesocarp ${ }^{2}$ seeds are mistakenly called as nuts are used for mastication $^{3}$. The husks are used as an alternative to toothbrush ${ }^{4}$ and it is also used as a vermifuge in some parts of China ${ }^{5}$. The antimicrobial activity of the betel quid is known due to the discovery that even the betel leaf alone can contribute effectively since it contains alkaloids. The four major alkaloids found in Areca catechu L. are arecoline, arecaidine, guvacoline, and guvacine. Arecoline is an oily-liquid that is soluble in water, alcohols and ether; this lipophilic nature can have an entry to the brain and intracellular spaces to fulfil its stimulatory effects ${ }^{6}$. Periodontal diseases are infections caused by bacteria that affect the supporting structures of the teeth such as the gingiva, cementum, periodontal membrane and alveolar bone. Gingivitis, a condition where the gums are inflamed, is associated with accumulations of bacterial plaque. Consequently, evidences support that normal flora of the oral cavity can partake in occurrence of various systemic diseases. The antimicrobial effect of ethanol extract of Areca catechu L. seeds against mixed-oral flora and certain-gram negative clinical isolates were tested using agar-well diffusion method as in the work of Cyriac, et al, $(2012)^{7}$. Their work demonstrated positive antimicrobial properties of Areca catechu L. nut husk against Candida albicans but not against gram-negative isolates. Thus, we conducted a study on the antimicrobial effects of ethanol extract of Areca catechu L. nuts/seeds against mixed-oral flora and gram-negative clinical isolates.

\section{MATERIALS AND METHODS}

Areca catechu L. nuts were harvested and verified by the National Museum, Botany Division, Manila, Philippines. Ethanolic extract was prepared by authorized personnel from the Chemicals and Energy Division, Department of Science and Technology. $430 \mathrm{~g}$ of Areca catechu L. nuts were pulverized using Wiley mill and soaked in $1.4 \mathrm{~L}$ of $95 \%$ ethyl alcohol for 48 hours. The filtrate was concentrated using rotary evaporator at $60^{\circ} \mathrm{C}$ under vacuum for 2 hours. Concentrated extract was further evaporated using water bath at $60^{\circ} \mathrm{C}$ to obtain a semi-solid extract (Crude extraction of $430 \mathrm{~g}$, areca nut produced 1.2 $\mathrm{L}$ ethanol extract and concentration of filtrate yielded 65.0 $\mathrm{g}$ of semi-solid extract) and diluted to $30 \%, 50 \%$, and 70 $\%$ concentrations which were then autoclaved prior to use. Mixed-oral flora inoculums were prepared by 
harvesting tooth scum and inoculating it in Tryptic soy broth (TSB). Gram-negative laboratory isolates were also inoculated in TSB. Both inoculums were incubated at $35^{\circ} \mathrm{C}$ for 24 hours and adjusted to $0.5 \mathrm{McF}$ arland prior to seeding in MHA plates bored with wells of $6 \mathrm{~mm}$ in diameter and $4 \mathrm{~mm}$ depth where varying dilutions (30\%, $50 \%$ and $70 \%$ ) of Areca catechu L. nuts ethanol extract were subjected for agar well diffusion antibiotic susceptibility testing. MHA test plates were incubated at $35^{\circ} \mathrm{C}$ for 24 hours and read for zones of inhibition using a Vernier calliper. Control antibiotics of Cefepime, Clindamycin, Erythromycin, and Tetracycline were used as reference antibiotics for mixed-oral flora test inoculums and Ciprofloxacin was used as a reference antibiotic for gram-negative laboratory isolates. All tests were done in duplicate and the mean computed.

\section{RESULTS}

Cefepime was most effective against all mixed-oral flora compared to other reference antibiotics with zones of inhibition ranging from $21 \mathrm{~mm}$ to $32 \mathrm{~mm}$ with a mean zone of inhibition of $28 \mathrm{~mm}$. Clindamycin on the other hand was least effective in inhibiting mixed-oral flora inoculums. There were no zones of inhibition $(0 \mathrm{~mm})$ observed in mixed-oral flora inoculums A and B against this reference antibiotic. Ciprofoxacin, used as the reference antibiotic for eight gram negative isolates in the study and demonstrated a mean zone of inhibition of 28 $\mathrm{mm}$ with susceptible patterns on all gram-negative isolates except for $E$. coli and $P$. vulgaris which demonstrated $8 \mathrm{~mm}$ and $15 \mathrm{~mm}$ zone of inhibition respectively. Table 1 showed that as the concentration of Areca catechu L. nut ethanol extract increases, zones of inhibition also increased. Identical or smaller zones of inhibition observed in higher concentrations can be attributed to the high viscosity of the ethanol extract which hinders the efficient diffusion of the active component throughout the agar matrix. This is the primary reason why $100 \%$ or pure ethanol extract of Areca catechu L. nut was not used in the study; it was very viscous and does not evenly diffuse throughout the agar. Although it exhibited larger zones of inhibition at times compared to $70 \%$ ethanol extract, there is great difficulty in measuring its zone of inhibition owing to the irregular pattern of diffusion of the highly viscous extract in the agar. Susceptibility patterns from mixed-oral flora $\mathrm{A}, \mathrm{B}, \mathrm{C}$, and D indicates that there were organisms in the mixed microbial community in the oral cavity isolated from tooth scum that were all susceptible to Cefepime, Clindamycin, Erythromycin, and Tetracycline; there were however, organisms that were also resistant to the same antibiotics as demonstrated in mixed-oral flora A which were resistant to Clindamycin, Erythromycin, and Tetracycline and mixed-oral flora B which were resistant to Clindamycin. For both cases of mixed-oral flora A and B organisms which demonstrated resistant patterns against Clindamycin, their microscopic observation shows that these were yeast cells and for the case of mixed-oral flora A, organisms which were found to be resistant to Erythromycin and Tetracycline, microscopic examination shows that these were gram-negative bacilli. All concentrations of ethanol extract of Areca cathecu L. nut demonstrated zones of inhibition against mixed-oral flora $\mathrm{A}, \mathrm{B}, \mathrm{C}$, and $\mathrm{D}$ with the smallest diameter measuring 7 $\mathrm{mm}(30 \%$ in mixed-oral flora B, Figure 1) and the largest measuring $18 \mathrm{~mm}(50 \%$ and $70 \%$ in mixed-oral flora $\mathrm{C}$, Figure 2 and 3). Minimum inhibitory concentration of Areca catechu L. nut ethanol extract effective against mixed-oral flora isolated from tooth scum was found to be $30 \%$ concentration with $9 \mathrm{~mm}, 7 \mathrm{~mm}, 16 \mathrm{~mm}$, and 17 $\mathrm{mm}$ zones of inhibition for mixed-oral flora A, B, C, and $D$ respectively. Mean diameter of zones of inhibition from duplicate trials of the varying concentrations of Areca catechu L. nut ethanol extract demonstrated antimicrobial activity against all gram-negative clinical isolates $(E$. coli, $K$. pneumonia, $P$. vulgaris, $P$. aeruginosa, S. non-typhi, $S$. typhi, $S$. flexneri and $V$. cholerae). The smallest mean of zones of inhibition were seen in $E$. coli with $8 \mathrm{~mm}$ at 30 $\%$ concentration (Figure 4 ) and $K$. pneumoniae which demonstrated no zone of inhibition in both $30 \%$ and 50 $\%$ concentrations indicating that Areca cathecu L. nut ethanol extract is least effective for these two organisms, particularly $K$. pneumoniae which produces a very thick capsule layer which can be observed in its highly mucoid colonial characteristic. Highest antimicrobial activity were demonstrated against $P$. vulgaris and $V$. cholerae which demonstrated a mean zone of inhibition of $18 \mathrm{~mm}$ at $70 \%$ concentration (Figure 5) and a mean zone of inhibition of $16 \mathrm{~mm}$ at $50 \%$ concentration (Figure 6) respectively; these results were comparable to intermediate susceptible pattern in Ciprofloxacin which is $16 \mathrm{~mm}$ to $20 \mathrm{~mm}$.

\section{DISCUSSION}

This study observed the antimicrobial activity of ethanol extract of Areca catechu L. nut in $30 \%, 50 \%$, and $70 \%$ concentrations against mixed-oral flora isolated from tooth scum and eight gram-negative clinical isolates namely: $E$. coli, $K$. pneumoniae, $P$. vulgaris, $P$. aeruginosa, S. non-typhi, S. typhi, S. flexneri and $V$. cholerae. Agar well diffusion method was used to evaluate antimicrobial activity by measuring zones of inhibition $^{8}$; all tests were done in duplicate and demonstrated clear evidences of antimicrobial activity. The use of mixed-oral flora in this study served as an effective simulation of the in-vivo microbial community found in the oral cavity in an in-vitro test environment. The oral flora which is commonly composed of organisms including bacteria, fungi, mycoplasma, protozoa and viral flora which may persist from time to time although, bacteria are the predominant group ${ }^{9}$ composed mainly of Streptococcus mutans, Streptococcus salivarius, Streptococcus anginosus, Streptococcus mitis and Lactobacillus acidophilus ${ }^{10}$. Areca catechu L. nut contains 50-60\% sugars, $15 \%$ lipid (glycerine of lauric, myristic and oleic acid), $15 \%$ condensed tannins (phlobatannin, catechin), polyphenolics (NPPF-86IA, NPF-86IB, NPF-86A and NPF-86B) and 0.2-0.5\% alkaloids (arecoline, arecaidine, guvacine and guvacoline ${ }^{11,12}$; these alkaloids, tannins and polyphenols possess antihelminthic, antifungal, antibacterial, antiinflammatory and antioxidant activities ${ }^{13}$. 
Chin, Ayessa A et al / Int. J. Res. Ayurveda Pharm. 4(6), Nov-Dec 2013

Table 1: Zones of Inhibition Observed in Mixed-oral flora and Gram-negative Clinical isolates

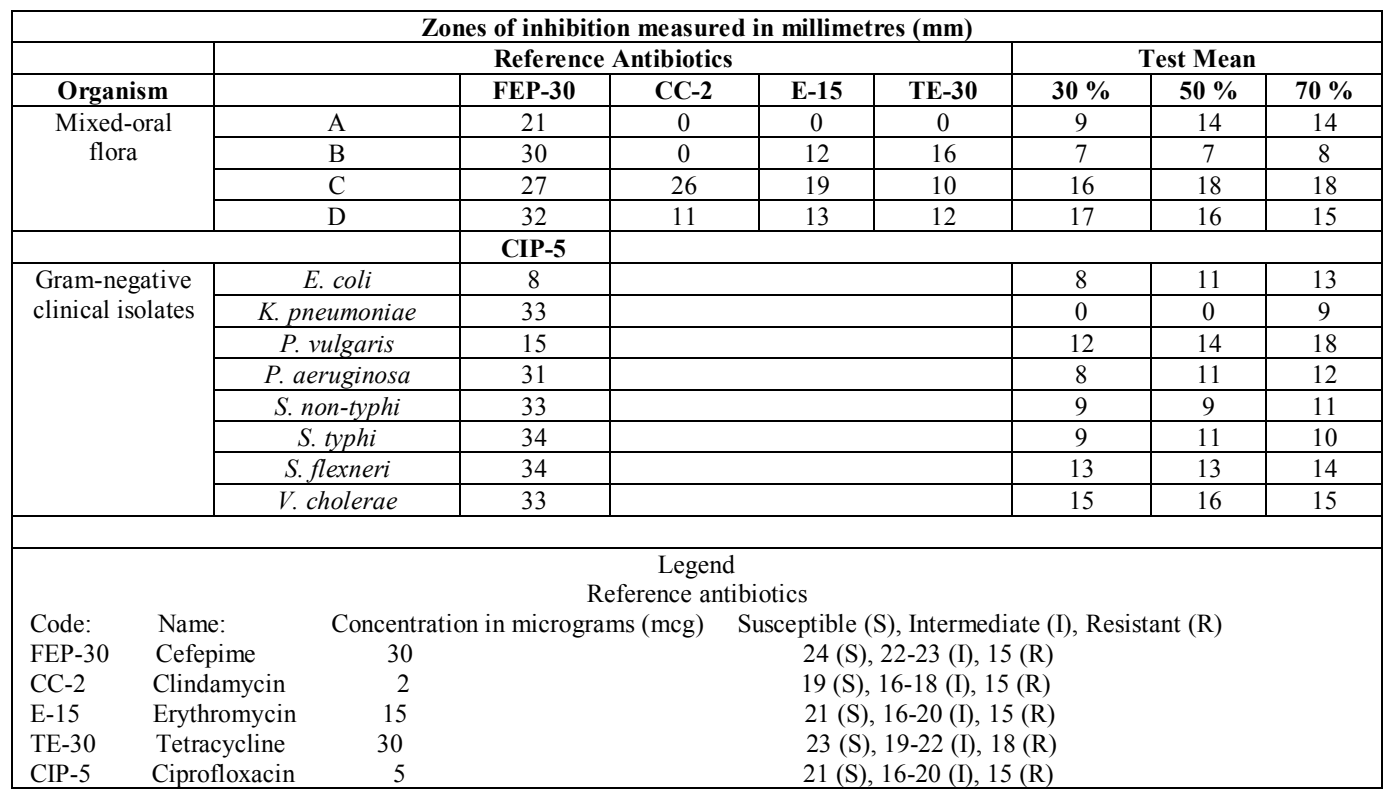

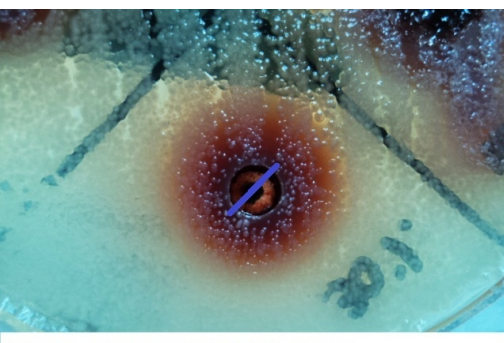

Mixed-oral flora B, 30\%, $7 \mathrm{~mm}$

Figure 1: mixed oral flora $B, 30 \%, 7 \mathrm{~mm}$

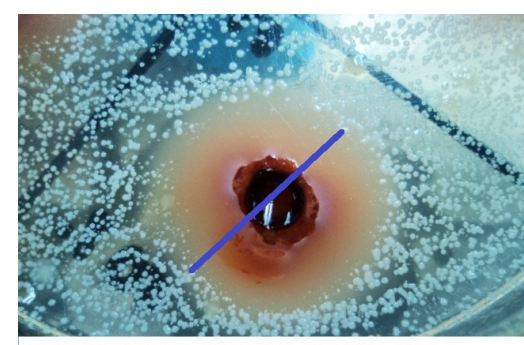

MIXED-ORAL FLORA C, 50\%, $18 \mathrm{~mm}$

Figure 2: mixed-oral flora C, $50 \%, 18 \mathrm{~mm}$

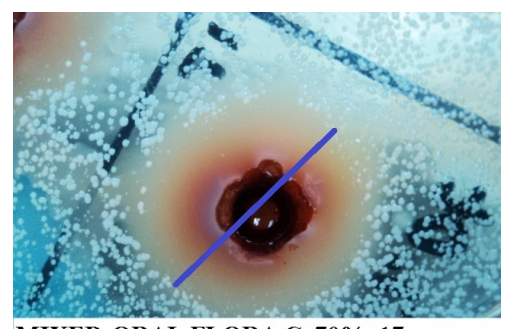

MIXED-ORAL FLORA C, 70\%, $17 \mathrm{~mm}$

Figure 3: mixed-oral flora C, $70 \%, 17 \mathrm{~mm}$

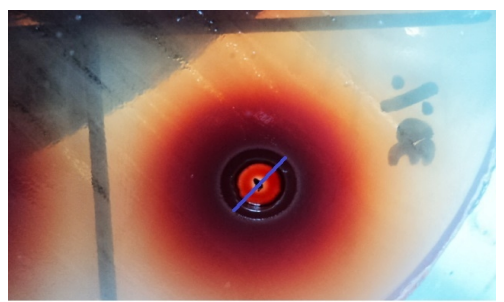

E. coli, $30 \%, 8 \mathrm{~mm}$

Figure 4: E. coli, $30 \%, 8 \mathrm{~mm}$

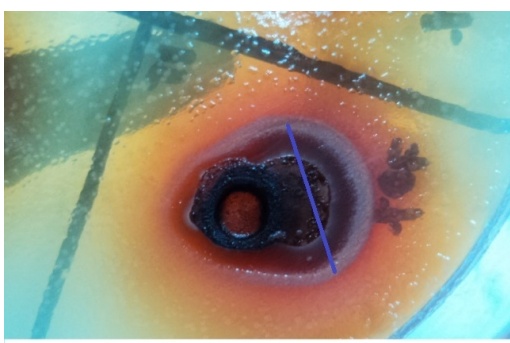

P. vulgaris, 70\%, $17 \mathrm{~mm}$, Trial 1

Figure 5: P. vulgaris, $70 \%, 17 \mathrm{~mm}$ (Trial 1)

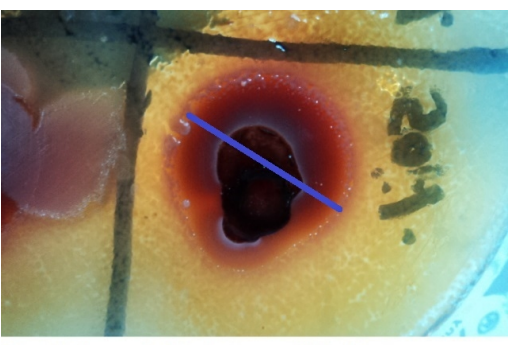

V. cholerae, $50 \%, 15 \mathrm{~mm}$, Trial 1

Figure 6: $V$. cholerae, $50 \%, 15 \mathrm{~mm}$ (Trial 1) 
In a study by Anjali and Rao (1995) water and methanol extracts of the seeds in various ages presented higher percentage of tannin and total phenols than other parts of the areca tree extracts ${ }^{13}$ which makes the nut an abundant source of bioactive components with antimicrobial activity. Areca cathecu L. nut extracts in this experiment proved hard to manage when incorporated in systems with protein constituents like broth media. It produced instant turbidity when applied; which is the primary reason why the researchers used plated media methodology for evaluating antimicrobial activity. Formation of turbidity was attributed to areca extract constituents capable of effectively and instantly precipitating proteins. In line with these it can be suspected that areca extract constituents may have strong effects in inhibiting signal molecules elucidated by microbes by denaturing it. Mixed oral floras from tooth scum were used to simulate, for the first time, the in vitro growth behaviours of microbes in the actual community they were isolated from.

This way the researchers demonstrated the antimicrobial activity of Areca catechu L. nut ethanol extract on mixed microbial community without eliminating the synergistic or antagonistic effect that each microbe exert on each other. Inhibitory effects were demonstrated in this study set up by zones of inhibition which can be attributed to the alkaloids in areca-nut ${ }^{14}$ and was clear evidence that the ethanol extract does exert an antimicrobial effect on some microbes found in the oral cavity even if they are incorporated in mixed biofilm communities. Furthermore, similar effects of inhibition were observed in varying degrees against the eight gram-negative clinical isolates. Also, betel quid extracts are mutagenic against bacteria; similar studies of aqueous extracts of areca nut produced gene conversion in yeast and arecoline and other arecanut alkaloids gave positive responses in most bacterial mutagenicity assays ${ }^{15}$. A study by Ghanwate and Thakare (2012) demonstrated that all ingredients of betel quid showed reduction in microbial population of oral cavity individually and in different combinations, betel nut decreased oral flora greatly; and showed highest antimicrobial activity against enteric pathogens ${ }^{16}$ which confirmed the results of this study as similar inhibitory effects were demonstrated against S. typhi, S. non-typhi, $S$. flexneri and $V$. cholerae. Studies by De Miranda et al, (1996) reported that areca nut extract exerts a direct antimicrobial effect against oral bacteria, including $S$. mutans, S. salivarius, $C$. albicans, and $F$. nucleatum ${ }^{17}$ which also correlates with the results of this study against mixed-oral flora. In betel quid chewing, auto-oxidation of polyphenols in areca nut generates the superoxide anion $\left(\mathrm{O}_{2}^{\left.-{ }^{-}\right)}\right.$especially at the high $\mathrm{pH}$ of slaked lime. The superoxide anion is converted to $\mathrm{H}_{2} \mathrm{O}_{2}$ which reacts in the presence of copper and iron to generate hydroxyl radicals which are toxic to some bacteria and fungi ${ }^{18,19}$. Conversely, results in other studies demonstrate that decrease in oxidation-reduction potential of the gingival region and in the $\mathrm{pH}$ pose restrictions in antimicrobial action of bioactive components of areca nut extract as shown in the study by Kenney et al, (1975) where there were no inhibition for gram-negative anaerobic bacteria which causes dental caries ${ }^{20}$. Regarding the antifungal property of Areca catechu L. extract, a study by Cyriac et al, (2012) demonstrated inhibitory effects against Candida albicans with zones of inhibition measuring 6 $\mathrm{mm}$ in diameter in MHA agar using $50 \mathrm{ul}$ extract of the nut husk alone ${ }^{7}$; it tested its antimicrobial activity against oral pathogens namely: $C$. albicans, $S$. mutans, $S$. salivarius, $S$. mitis, L. acidophilus, and P. intermedia and demonstrated positive result only for $C$. albicans and no effect against the other oral pathogens. This can be explained by the results of our study; resistant organisms in mixed-oral flora in this study were found to be yeast cells which may or may not be C. albicans; suffice to say, there may be bioactive components present in the husk that is specifically effective against $C$. albicans but not against other oral pathogens. In addition, bioactive components against bacteria may be present in the husk but in very low concentrations if not at all absent which is inadequate to demonstrate antimicrobial activity towards other oral pathogens. Conversely, there are bioactive components present in the Areca catechu L. nut ethanol extract which explains the antimicrobial effect exerted against mixed-oral flora organisms from tooth scum and clinical isolates in this study. The former rationale is evidence that there may not be any other constituents exerting antagonistic or negating effects to inhibit the positive action of the bioactive agents present in the ethanol extract of Areca catechu L. nut ${ }^{21}$. In summary, ethanol extract of Areca catechu L. nut possess antimicrobial properties when applied in aerobic environments owing to the dependency of the bioactive agents in oxidation-reduction reactions ${ }^{18-20}$. Unidentified bioactive components elicit precipitation of proteins which may explain its antimicrobial potency of inhibiting proliferation of mixed bacterial community enclosed in bio films as exhibited by its inhibitory effect against several models of mixed-oral flora. It is highly recommended that the bioactive agents responsible for precipitating proteins be identified and quantified for applications in disrupting the functions of signalling molecules as well as in other laboratory methodologies having for its principle protein precipitation.

\section{ACKNOWLEDGEMENTS}

The authors would like to express their gratitude to Wilfredo F. Vendivil Ph.D, Curator II the National Museum, Botany Division, Manila, Philippines for authenticating the identity of the harvested Areca catechu L. nuts and Romulo R. Estrella of the Chemicals and Energy Division of the Department of Science and Technology for preparation of the ethanolic extract.

\section{REFERENCES}

1. Staples GW and Bevaqcua RF. Areca catehu (betel nut palm), www.traditionaltree.org; 2006.

2. Kurian JC. Amazing Healing Plants Vol. 1. Manila, Philippines. Philippine Publishing House; 2010.

3. Rummel DJ. Useful Plants of the Philippines Vol. 1.Quezon City, Philippines. C and E Publishing Inc; 2005.

4. Baja Lapis AC, David M, Reyes C, Audije BS. ASEAN's 100 Most Precious Plants. Philippines. European Union-ASEAN Regional Centre for Biodiversity Conservation; 2004.

5. Zhang WM, Wei J, Chen WX, Zhang HD. The Chemical Composition and Phenolic Antioxidants of Areca (Areca catechu L.) Seeds. http://www.ier-institute.org/2160-0589/abe1/v12/016.pdf; 2011.

6. Ferrera FD. Arecoline (Betel Nuts). http://flipper.diff.org/app/ items $/ 1371 ; 2008$.

7. Cyriac MB, Pai V, Varghese I, Shantaram M, Jose M Antimicrobial Properties of Areca catechu (Areca nut) Husk 
Chin, Ayessa A et al / Int. J. Res. Ayurveda Pharm. 4(6), Nov-Dec 2013

Extracts Against Common Oral Pathogens, International Journal of Research in Ayurveda and Pharmacy 2012; 3(1): 81-84.

8. Tseng CC, Wolff LF. Inhibitory Effects of Stannous Fluoride and other commonly used antibacterial agents on oral bacteria. J Formos ed Assoc 1991; 90: 565-571.

9. Bowden GHW. Microbiology of root surface caries. Journal of Dental Research 1990; 69: 1205-1210. http://dx.doi.org/10.1177/ 00220345900690051701 PMid:2186069

10. Bowden GHW and Hamilton IR. Survival of Oral Bacteria. Critical Reviews in Oral Biology and Medicine 1990; 9: 54-54. http:/ /dx.doi.org/10.1177/10454411980090010401

11. Reijiro U, Toshiharu M, Masaya I, Yasuhiro T, Akira F. New 5nucleotidase Inhibitors NPF-86IA, NPF-86IB, NPF-866 A and NPF-86 B from Areca catechu. Part: Isolation and Biological properties. Planta Medica 1998; 54: 419-422.

12. Wetwitayaklung $P$, Phaechamud T, Limmatvapirat C, Keokitichai S. The Study of Antioxidant Capacity in Various Parts of Areca Catechu L., Naresuan University Journal 2006; 14(1): 1-14.

13. Anjali $\mathrm{S}$ and Rao AR. Modulatory Influence of Areca Nut on Antioxidant 2(3)-tert-butyl-1-4hydorxyanisole-induced Hepatic Detoxification System and Antioxidant Defence Mechanism in Mice. Cancer Letters 1995; 91: 107-114. http://dx.doi.org /10.1016/0304-3835(95)03727-E

14. http://www.rooneyarchive.net/lectures/betel_chewing_in_southeast_asia.pdf; 2013.

15. Tsai YS, Lee KW, Huang JL et al. Arecoline, A Major Alkaloid of Areca Nut, Inhibit p53, repress DNA repair, and Triggers DNA Damage Response in Human Epithelial Cells. Toxicology 2008;
249: 230-237. http://dx.doi.org/10.1016/j.tox.2008.05.007 PMid:1 8585839

16. Ghanwate $\mathrm{N}$ and Thakare P. Antimicrobial and Synergistic Activity of Ingredients of Betel Quid on Oral and Enteric Pathogens. Bioscience Discovery 2012; 3(1): 47-51.

17. De Miranda CM, Van Wyk CW, Van Der Biji P, Basson NJ. The Effect of Areca Nut on Salivary and Selected Oral Microorganisms. Int Dent J 1996; 46: 350-356. PMid:9147124

18. Nair UJ, Floyd RA, Nair J et al. Formation of reactive oxygen species and of 8-hydroxy deoxyguanosine in DNA in vitro with Betel Quid Ingredients. Chem Biol Interact 1987b; 63: 157-169. http://dx.doi.org/10.1016/0009-2797(87)90095-0

19. IARC. Betel-Quid and Areca Nut Chewing and Some Areca Nut Derived Nitrosamines. IARC Monogr Eval Carcinog Risks Hum 2004; 85: 1-334. PMid: 15635762

20. Kenney EB, Saxe SR, Bowles RD. The Effect of Cigarette Smoking on Anaerobiosis in the Oral Cavity. J Periodontol 1975; 46: 82-85. http://dx.doi.org/10.1902/jop.1975.46.2.82 PMid:235017

21. Parekh J, Chanda S. Antibacterial and Phytochemical Studies on 12 Species of Indian Medicinal plants. African Journal of Biomedical Research 2007; 175-181.

\section{Cite this article as:}

Chin, Ayessa A., Fernandez Clariza D., Sanchez Renalyn B., Santos Beatriz Marie S., Tolentino Regine F., Masangkay Frederick R. Antimicrobial performance of ethanolic extract of Areca catechu L seeds against mixed-oral flora from tooth scum and gram negative laboratory isolates. Int. J. Res. Ayurveda Pharm. 2013;4(6):876-880 http://dx.doi.org/10.7897/2277-4343.04620 